\title{
新規摂動ツールによる細胞遊走の分子機構解明
}

\author{
井上 尊生
}

\section{Unraveling Molecular Mechanism of Cell Migration Using Novel Perturbation Tools}

\author{
Takanari Inoue \\ Johns Hopkins University, School of Medicine, Department of Cell Biology; \\ 855 N. Wolfe St., 453 Rangos, Baltimore, MD 21205, USA.
}

(Received January 2, 2014)

\begin{abstract}
Complexity in signaling networks is often derived from co-opting particular sets of molecules for multiple operations. Understanding how cells achieve such sophisticated processing using a finite set of molecules within a confined space - what we call the "signaling paradox"- is critical to cell biology and bioengineering as well as the emerging field of synthetic biology. We have recently developed a series of chemical-molecular tools that allow for inducible, quick-onset and specific perturbation of various signaling molecules. The present technique has been employed to unravel several important, previously unresolved questions regarding the regulatory mechanisms of potassium ion channels, the membrane targeting mechanisms of small GTPases and positive feedback machinery in neutrophil migration. Using this novel technique in conjunction with conventional fluorescence imaging and biochemical analysis, we are currently further dissecting intricate signaling networks in living cells. Ultimately, we will generate completely orthogonal machinery in cells to achieve existing, as well as novel, cellular functions. Our synthetic, multidisciplinary approach will elucidate the signaling paradox in cells created by nature.
\end{abstract}

Key words_— chemotaxis; chemically inducible dimerization; feedback signaling; cell polarization; synthetic cell biology

\section{はじめに}

細胞走化性は, 細胞が外部にある化学物質の濃度 勾配を検知し，その情報に基づき適切な方向へ遊走 する性質である。血管新生や肧発生，創傷治癒，免 疫防御, 神経回路形成などを含む様々な生理現象に おいて重要な役割を担っており，その障害は，これ ら生理現象に異常をきたすだけでなく，がん細胞の 転移や関節炎などの進行を促す。細胞走化性は段階 的なプロセスで，細胞の極性化，前部での仮足形 成，後部の収縮からなる (Fig. 1)。最初の極性化 は，環境中の化学物質により誘発される.1) 非極性 細胞は，化学物質の濃度勾配に応じて，一連のシグ ナル分子（Rac，PI3K，RhoA，PTENなど）を細胞 の片側に蓄積し，極性化する。つづいてこれらの分

The author declares no conflict of interest.

Johns Hopkins University, School of Medicine, Department of Cell Biology (855 N. Wolfe St., 453 Rangos, Baltimore, MD 21205, USA)

e-mail: jctinoue@jhmi.edu

本総説は, 平成 25 年度日本薬学会奨励賞の受賞を記念

して記述したものである。
子がアクチンの重合・脱重合を促すことにより仮足 を形成する。仮足は細胞が前へ進む原動力を与え る. 最後に細胞の後部が収縮することで一連の走化 性プロセスが完結する，好中球は体の中で最も速く 遊走する体細胞であり，走化性のモデル系として汎 用されている。個体が菌に感染すると，好中球は菌 から放出される化学物質をいち早く検出し, その濃 度勾配を基に感染部位に到達し，菌を捕食する。好 中球の濃度勾配検出感度は非常に高く, 細胞の端か ら端までで $1 \%$ の濃度勾配であっても高い信頼度を もつて遊走の方向を決定する. $\left.{ }^{2}\right) 1 \%$ の濃度勾配と は，すなわち細胞の片側で 100 分子の化学物質があ ると，反対側に 99 分子あるという状況である. 細 胞膜受容体に結合した化学物質の平衡を加味する と, 細胞の前後における受容体活性化の摇らぎは, $1 \%$ 差よりも大きくなる. このようにノイズが優 勢となる状況で，いつたい好中球がどのようにして 化学物質の信号を検出し，堅牢に遊走の方向性を決 定しているのかは, 細胞遊走の研究において最大の 問題の 1 つとなっている. 過去数十年の研究から, 
これまでに多数のシグナル分子が細胞走化性の制御 に関与していることが明らかにされてきた．また数 理モデルによって，細胞遊走の情報処理は，正と負 の 2 つのフードバックによって説明できることが 示された。しかしながら，細胞走化性に関与する分 子群が，どのようなシグナル様式でもって化学物質 の濃度勾配を検出し，適切な方向へ細胞を遊走させ ているのかを詳細に記述することはいまだに困難を 極めている，その大きな理由の 1 つに，実験手法の 欠如が挙げられる．好中球は秒から分のオーダーで 環境情報を処理し，速やかに極性化と遊走を達成す るため，それと同等若しくはそれよりも早いオー ダーで分子の活性を制御する必要がある．従来の遺 伝学的手法（遺伝子ノックアウト, RNAi, タンパ ク過剩発現など）は，時間解像度が細胞内における シグナル伝達の速度と比べて遅いため，与えられた 摂動に対して細胞が 2 次的， 3 次的な反応を引き起 こした後の状態を観察していることになる。そのた め，途中の時間的な情報が失われ，非線形過程を実 験的に検証することが難しい。この問題を解決する にあたり，近年のオプトジェネティクスに基づいた 細胞内局所での標的タンパク質の素早い活性制御は 非常に有効である。例えば Weiner や Hahn らによ る光感受性植物タンパクを用いた Rac の活性化が 挙げられる。吕) この手法により，細胞内局所で Rac の活性を瞬時に変えることが可能となつたが，一般 性は非常に低く，いまだ Rac のみに適用可能で他 のタンパク質への応用が阻まれている。つまり，こ のような高い時空間解像度をもってタンパク質の活 性を制御できる手法は残念ながら限られている。そ こでわれわれは独自に開発した一連の分子駆動プ ローブを駆使して，好中球がどのようなシグナル様 式でもって環境情報の変化を高感度に検出している のかを時空間レベルで解明することを目指している.

\section{CRISP の開発}

私は大学院生のときに, 有機合成化学, 光化学及 び細胞生物学の技術・知識を結集することで，受容 体や酵素活性を生きた細胞内で，任意の時間と場所 で瞬時に不活化できる手法， small molecule-based laser inactivation（smCALI）を開発した（Fig. 2). 本手法を用いて， IP $\mathrm{IP}_{3}$ 受容体によるカルシウムの放 出機構を分子レベルで解明した。また本手法は，時 空間的に $\mathrm{IP}_{3}$ 受容体の生理機能を制御できることか
ら細胞内ネットワーク解析の有力な新手法になり得 るもので, 将来的には創薬基礎研究にもつながると 考えている. しかしながら，細胞遊走に係わるシグ ナル分子は非常に多様で，こうした広範な分子の活 性制御には smCALI は不向きであった。なぜなら， smCALI のプローブ開発において標的分子に結合 するが分子活性には直接影響を与えないリガンド分 子が必須であり，そうしたリガンド分子は一般的に あまり知られていないからである，例えば，PI3 キ ナーゼや低分子量 $\mathrm{G}$ タンパク質である Rac が代表 的な細胞遊走を支配する分子であるが，これらを smCALI で標的とすることは技術上困難であった。

そこで私は博士研究員のときに chemically-triggered, rapidly-inducible, and compartment-specific perturbation（CRISP）を開発した。CRISP の原理 は，2 種類のタンパク質（FKBP と FRB）の会合を 1 つの小分子（ラパローグ）により誘導するもので ある [Figs. 3 (a) and (b) ]。この原理は 20 年前の 1993 年に Schreiber と Crabtree らによって開発さ れた. ${ }^{5)}$ CRISP という名前は一般的な名称ではない が，この原稿内で簡便的に使わせて頂く．われわれ はこの原理に基づき，多面的に改良を加えること で，生きた細胞内で，任意のタンパク質の活性を秒 のオーダーで，任意の細胞内局所で制御できる手法 を構築した. ${ }^{6,7)}$ Figure 3 (a) に示すように，CRISP では細胞内に FKBP（濃青色）と任意のタンパク質 （水色）の融合タンパク質（以後 CRISP プローブ と呼ぶ），そして細胞膜に局在する FRB（赤色）を 使用する. ラパローグ添加により FKBP と FRB と の会合を誘導すると，結果として CRISP プローブ が細胞膜へと移行する．多くの細胞内シグナル分子 は，細胞膜の受容体刺激に伴い，細胞膜へ移行する ことで情報伝達系を開始させるが，ラパローグによ る強制的な CRISP プローブの膜移行はこれを模倣 しつつも，受容体の活性化を介することなく任意の

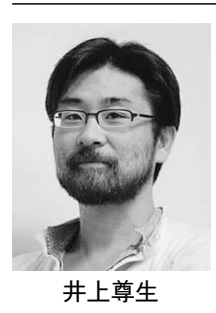
2003 年に東京大学薬学系研究科博士号 取得後, 米国スタンフォード大学医学 部ケミカル\&システムズバイオロジー 博士研究員を経て 2008 年から米国ジョ ンズホプキンス大学医学系研究科細胞 生物学部で主任研究員として研究室を 運営. 構成生物学の概念に基づき, 摂 動ツールを開発・改良し, 細胞遊走の 分子機構解明及び再構築に取り組む。 http://www.jhu.edu/inouelab/home.html 
細胞内情報伝達系を活性化することができる．また FRB の局在を変えることで，ミトコンドリアやゴ ルジ体など様々な細胞内小器官に標的タンパク質を 秒のオーダーで移動させることができる．CRISP

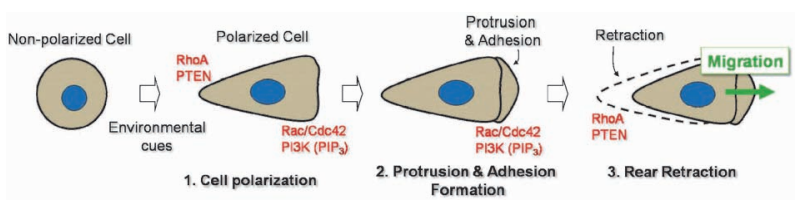

Fig. 1. Three Signature Steps in Cell Migration

Non-polarized cell migrates through three steps upon sensing environmental cues; polarization, protrusion and retraction. Molecules involved in each step are indicated in red.

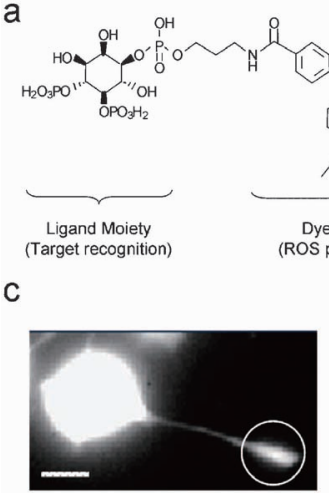

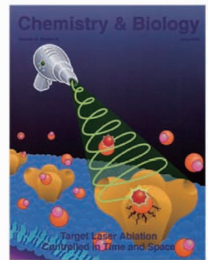

d

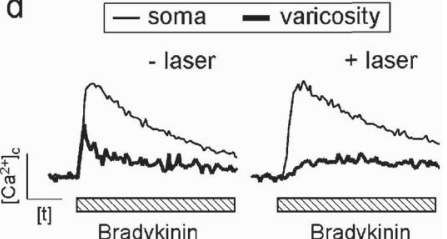

Fig. 2. Spatio-temporal Dissection of $\mathrm{IP}_{3}$-induced $\mathrm{Ca}^{2+}$ Release

(a) Chemical structure of $\mathrm{MGIP}_{3}$. (b) Cover art from Chemistry \& Biology. (c) Subcellular region of a PC12 cell (white circle) was illuminated by laser light. Scale bar, $10 \mu \mathrm{m}$. (d) Bradykinin-induced intracellular $\mathrm{Ca}^{2+}$ was monitored in both soma (thin lines) and varicosity (thick lines) of the same cell in the presence or absence of laser illumination.
の最大の特徵は，速い摂動（<10 秒）を生きた細 胞内で達成できることと，一般性が高いこと，すな わち様々なタンパク質への応用が容易なことであ る。例えば筆者は，Rac，Cdc42，RhoA などの低分 子量 $\mathrm{G}$ タンパク質の活性を素早く制御することに より，細胞骨格が直接影響を受け，迅速に細胞の形 が変化することを示した [Fig. 3(c) ]. ${ }^{6)}$ また細胞膜 の $\mathrm{PI}(4,5) \mathrm{P}_{2}$ や $\mathrm{PIP}_{3}$ といったリン脂質の濃度を生 きた細胞内で瞬時に変化させることで，長年議論の 絶えなかつたイオンチャネルの活性制御機構8) や低 分子量 $\mathrm{G}$ タンパク質の膜局在機構9)を解明した。こ うした低分子量 $\mathrm{G}$ タンパク質やリン脂質を in situ で特異的かつ素早く制御する摂動ツールは前例がな く, CRISP を適用することで得られた上記の知見 は，それぞれのコミュニティーに大きな影響を与え た。われわれは近年さらにCRISP を改良し，新規 に合成した光応答性のラパローグを用いて，任意の 細胞内局所で分子活性を制御したり，10) さらにはラ パローグの系とは完全に独立した，新しいCRISP の系を植物ホルモンであるジベレリンの新規誘導体 とその結合タンパク質を用いて確立した. ${ }^{11)}$ ジベレ リンとラパローグという直交的に機能する 2 つの CRISP の確立により，2 種類の分子活性を同時, 又は異なる夕イミングで，そして 2 つ場所特異的 に制御できるようになった。また，ジベレリンはラ パローグとは異なり $\mathrm{mTOR}$ キナーゼを阻害しない ので，オートファジーなど mTOR の係わる情報伝 達系への適用が可能である，興味深いことに CRISP によるタンパク質の会合は秒のオーダーと速いのだ a
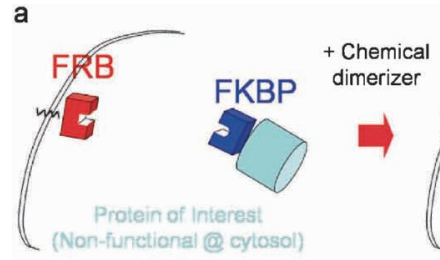

b

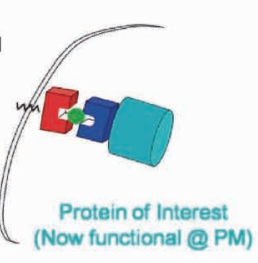

c

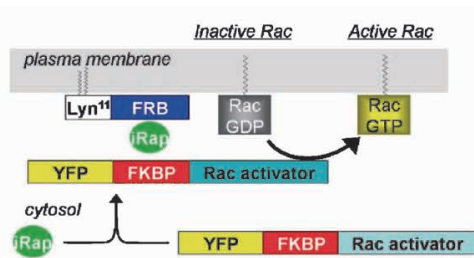

d
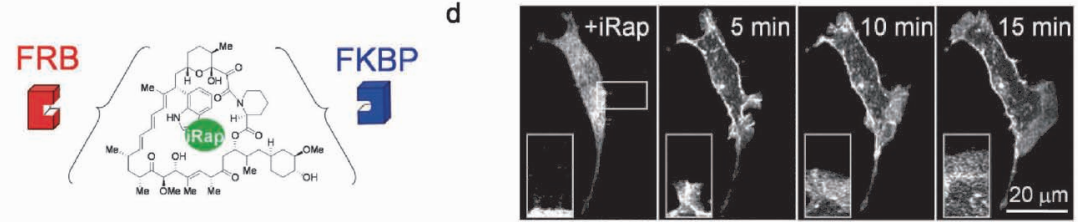

Fig. 3. Basic Principle of Chemically Inducible Translocation Strategy (CRISP)

(a) Chemical dimerizer such as rapamycin or iRap (shown as a green ball) induces membrane translocation of FKBP fusion protein to form tripartite complex with membrane-tethered FRB. (b) Chemical structure of iRap whose one side binds FRB, the other FKBP. (c) Principle of Rac activation with translocatable Rac activator. (d) Inducible Rac activation in fibroblast led to a remarkable lamellipodia formation. 
が，細胞内での見かけの解離は非常に遅いことが観 察されている. ${ }^{12)}$ その理由ははっきりとは分かって いないが，われわれは大きく2つの原因が寄与して いると考えている．1つは FKBP と FRB の高い親 和性である。ラパローグとの結晶構造解析による と，ラパローグと FKBP， ラパローグと FRB 間に 密な結合があり個々の結合の親和性も高いのだが, これに加えて FKBP と FRB も直接水素結合してお り，強固な複合体を形成している。実際，FKBP • rapamycin - FRB 複合体の解離速度定数は, $10^{-2}$ $\mathrm{s}^{-1}$ オーダーであることが報告されており，オフ レートは比較的遅い。しかし, 解離速度が $10^{-2} \mathrm{~s}^{-1}$ 程度であることを鑑みれば，系内からラパローグを 完全に除去する条件において計算上では 10 分程度 で 99\%近くが解離することになる。しかし，細胞 外液を繰り返し入れ替えて洗浄を行ったとしても, 実際にはそうはならない。細胞内で解離が遅いもう 1 つの理由は，ラパローグの細胞内のクリアランス が低いことにあると考えられる。 クリアランスの低 さは，ラパマイシンが高脂溶性の分子で，脂質膜や タンパク質表面など, 細胞内外の様々な場所に吸着 し, 細胞内から洗い出すことが難しいことに由来し ている．また細胞がこうした化合物を汲み出すポン プを持っていないことも一因であると予想してい る。これらの効果により堅牢な複合体を形成し，細 胞内の異常に遅いオフレートに寄与すると考えてい る．生体内のすべての情報伝達系は可逆的である. よって，より生理的な摂動を与える意味で，また実 験手法としても分子活性の可逆的な制御は有用であ る.そこでわれわれはジベレリンとラパローグの 2 つの直交した系を有効に活用することで，一度結合 した FKBP・ラパローグ・FRB 複合体を解離せず に, 複合体全体を他の場所へ移動させることにより 分子活性をオンそしてオフすることに成功した. ${ }^{12)}$ この手法を用いることで可逆的な制御が可能となつ ただけでなく，タンパク質の局在を細胞質から形質 膜，そしてミトコンドリアへと次々と変化させる手 品のような楽しさを演出することもできた.

\section{細胞骨格と膜脂質}

細胞骨格と細胞膜のイノシトールリン脂質は非常 に緊密な関係にあり，またその相互作用は細胞走化 性において最も重要な役割の 1 つを担う。イノシ トールリン脂質は 8 種類知られているが，それらの
化学構造は大変似通っていて, 違いはリン酸の数と 修飾位置だけである。これら 8 種の脂質はお互いに 基質と生成物の関係にあり，それぞれの反応を担う 酵素によって相互変換されている，そのため従来の 遺伝子操作を用いてこれらの酵素量を変化させる と，細胞を観察する頃には目的の脂質だけでなく他 の多種類の脂質にも影響を及ぼしていることが多々 あり，こうした実験上の制約が細胞走化性やその他 の膜脂質が関連する細胞機能の研究において問題と なっていた．われわれの開発する CRISP プローブ の標的はタンパク質のみならず，遺伝子ではコード されないような情報伝達因子，例えば膜脂質の成分 を瞬時に操作することも可能である。これまで CRISP プローブとして細胞膜上のリン脂質を合成 又は分解する種々のプローブの開発に成功してお り，これらを用いることで $\mathrm{PIP}_{3}, \mathrm{PI}(4,5) \mathrm{P}_{2}$ などの 脂質の量を in situ で急速に調整することが可能と なつた．特に PI $(4,5) \mathrm{P}_{2}$ に対するプローブでは，非 常に興味深い結果を得ることができたので以下で紹 介する。，一般的には，PI $(4,5) \mathrm{P}_{2}$ の量を増やすため には，これを合成するためのPI 5 キナーゼを過剩 発現させる系が用いられるが，われわれはこれを CRISP プローブへと応用することで，任意のタイ ミングで急速に形質膜上の PI $(4,5) \mathrm{P}_{2}$ の量を制御す ることに成功した. ${ }^{8)}$ また CRISP プローブが，細胞 内の任意の場所に移動可能な性質を応用して，新た な PI $(4,5) \mathrm{P}_{2}$ 制御法として PI $(4,5) \mathrm{P}_{2}$ liberation 法 を確立した（Fig. 4)。 キナーゼによる PI $(4,5) \mathrm{P}_{2}$ in situ 合成では, PI $(4,5) \mathrm{P}_{2}$ 合成に伴い原料である PI4P が消費され濃度が低下するのに対し，PI (4, 5) $\mathrm{P}_{2}$ liberation 法では，PI $(4,5) \mathrm{P}_{2}$ をマスクする CRIPS プローブをミトコンドリア上へと格納する ことで, 急速に PI $(4,5) \mathrm{P}_{2}$ をシグナル伝達系へと解 放（liberation）でき，PI4P の量に直接影響を与え ず PI $(4,5) \mathrm{P}_{2}$ シグナルを活性化できる.この 2 つの ユニークな摂動法を用い, 細胞骨格であるアクチン の再構成系に対する影響を比較したところ，2つの $\mathrm{PI}(4,5) \mathrm{P}_{2}$ 摂動系が，同程度の $\mathrm{PI}(4,5) \mathrm{P}_{2}$ を生み出 す一方で，アクチンの骨格に対する表現系は排他的 に異なるという非常に興味深い結果を得た. ${ }^{13)}$ 原料 となる PI4P の減少を伴う in situ 合成では剛直なア クチン凝集束であるアクチンコメットを生み出した のに対し，PI4P 量に影響を与えない liberation 系 
では細胞辺縁部の編目状の構造を発達させ膜の波打 ち現象を誘起した（Fig. 4）。更なる詳細な検証に より, $\mathrm{PI}(4,5) \mathrm{P}_{2}$ 操作によるこれら細胞骨格の排他 的な表現系には，活性が排他的に制御される性質を 有する Rac-RhoA と，細胞内の膜輸送系が関与す ることが示唆された。これらにより，PI $(4,5) \mathrm{P}_{2}$ に よるアクチン骨格再構成の表現系は，これまで形質 膜上での役割がほとんど注目されてこなかった PI4P 量によっても多様化し得るという新しいモデ ルが提唱された。このような複数のリン脂質のシグ ナルが相互作用しつつアウトプットを決定するモデ ルは, PI $(4,5) \mathrm{P}_{2}$ という 1 種類の分子が情報伝達の 中核分子として多種多様な機能を実現し得る根源的 な機構として係わると考えている.

細胞走化性の極性化の分子機構解明と再構築へ向 けて

CRISP の細胞走化性研究への応用としてまず PI3 キナーゼの活性化を試みた。 PI3 キナーゼは細 胞走化性を引き起こす中心的な役割をしている。 そ こで CRISP を用いて PI3 キナーゼの酵素活性ユニ ットを細胞膜に瞬時に誘導する分子プローブを作製 し，好中球のモデルとして使われる HL-60 細胞に 導入した，そしてラパローグを加えると，それまで おとなしかつた細胞が急に形態を変化し遊走を始め ることが観察された。画像解析によると，この一連 の過程は HL-60 細胞を走化性物質で刺激したとき と，ほとんど遜色なかった，つまり，PI3 キナーゼ を刺激することと走化性物質を細胞外で受容するこ とは細胞遊走の観点でみればほぼ同義であり，受容 体から PI3 キナーゼをつなぐ G タンパクの経路は 単純に外部の刺激情報を細胞内に伝達することにの み貢献していると予測される。またこの実験を発展 させることで，ポジティブフィードバックによる $\mathrm{PI} 3$ キナーゼの酵素反応物である $\mathrm{PIP}_{3}$ をリアル夕 イムに定量化することが可能となった．それにより 細胞の先導端の仮足においてポジティブフィードバ ックにより $\mathrm{PIP}_{3}$ が活発に産生されることが観察さ れた。同様の実験を阻害剂存在下で行うことで，こ うした $\mathrm{PIP}_{3}$ 産生がアクチンの重合と PI3 キナーゼ の活性化という2つの条件が揃つて初めて起こるこ とを示した。つまりポジティブフィードバックは ブーリアンロジックゲートでいうところの AND ゲートを形成していた. ${ }^{14)}$
続いてマイクロ流路系をデザイン，工作し，流路 内においてラパローグの任意の濃度勾配を形成し た。細胞を流路内に閉じ込め，仮足形成に重要な Rac タンパクを細胞内で勾配を形成するように活性 化することで，細胞がラパローグの濃い方へ遊走す ることを示した。これは CRISP という構成的手法 を用いて，ラパローグという非生理的な化学物質に 対する細胞走化性を再構築した，極めて珍しい例で ある. ${ }^{15)}$ またこの実験には HeLa 細胞というもとも と走化性が得意ではない細胞を用いている。つま り，われわれは不活性な細胞に最小限の摂動を外部 から加えることで，新しい機能を付与することに成 功しており, 将来的には, こうした最小限の摂動に よる細胞機能の人工的なコントロールシステムが科 学技術や医療分野へ応用されることを期待してい る、マイクロ流路系の大きな特徵の 1 つは，溶質の 濃度及び濃度勾配を比較的自在に変化できることで ある．溶質の平均濃度は変えずに濃度勾配を変化さ せたり，濃度勾配を変えず平均濃度を変化させたり することが可能である，そこで，ラパローグの濃度 勾配や濃度そのものを变化させることで, 細胞の極 性化機構が活性 Rac 分子の濃度又は濃度勾配に支 配されているのかを調べた。具体的には細胞の極性 化のタイミングを 2 段階に分けて, 初期の極性化と 後期の極性化にかかる時間を様々なラパローグの条 件下で蛍光顕微鏡を用いて測定した。すると，初期 の極性化には活性 Rac 分子の濃度勾配が，後期に は活性 Rac 分子の濃度が支配的であることが観察 された（Fig. 5)。われわれは初期の極性化がアク チン重合に係わる分子の極性化を反映し，後期の極 性が細胞骨格及び細胞膜を含めた形態レベルでの極 性化であると考えている.

\section{今後の展開}

蛍光イメージングの発達と普及に伴い, 細胞内情 報伝達系への理解が一層深まっている。 その結果と して, 活性化, 不活性化による単純な一次線形的な シグナル様式だけではなく，フィードバック，クロ ストーク，時空間制御といつた，複雑な高次非線形 的な様式を含むことが明らかとなつた。しかしなが ら，このような複雑な系を検証できる摂動ツールの 開発は常にボトルネックとなってきた。今回紹介し た smCALI やCRISP などの技術は，様々な学問領 域（有機化学，遺伝学及びそれらの複合領域となる 

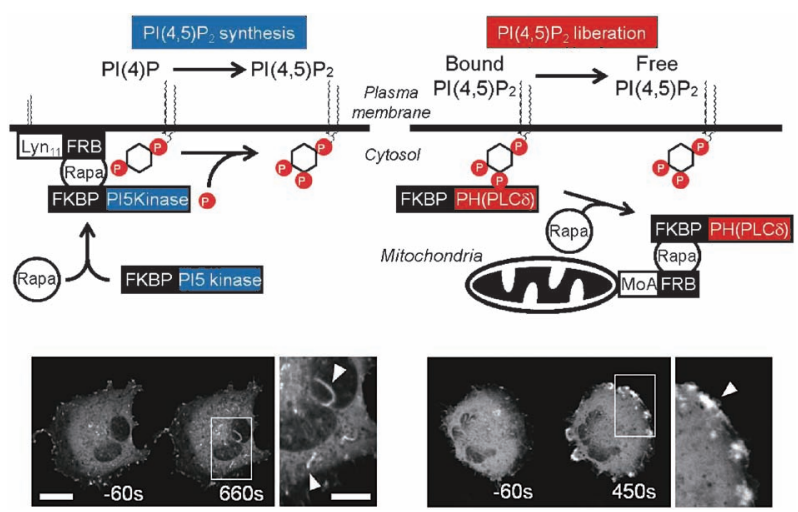

Fig. 4. Schematic Illustration of Two Techniques to Rapidly Manipulate PI $(4,5) \mathrm{P}_{2}$ Using CRISP

(Top panels) $\mathrm{PI}(4,5) \mathrm{P}_{2}$ synthesis: Upon addition of rapamycin, cytosolic FKBP-PI(4) P5K is recruited to the plasma membrane, resulting in phosphorylation at the D5 position of $\mathrm{PI}(4) \mathrm{P}$ to produce $\mathrm{PI}(4,5) \mathrm{P}_{2}$. $\mathrm{PI}(4,5) \mathrm{P}_{2}$ liberation: Prior to rapamycin addition, FKBP-PH $(\mathrm{PLC} \delta)$ is preferentially at the plasma membrane through interaction with $\mathrm{PI}(4,5) \mathrm{P}_{2}$. Upon rapamycin addition, FKBP-PH (PLC $\delta$ ) gets sequestered from the PM to mitochondria, leading to an increased concentration of free $\mathrm{PI}(4,5) \mathrm{P}_{2}$. (Bottom panels) Time-series confocal fluorescence images of YFP-FKBPPI (4) P5K before and after induction of actin comets (left) or membrane ruffles (right) as a result of $\mathrm{PI}(4,5) \mathrm{P}_{2}$ synthesis or $\mathrm{PI}(4,5) \mathrm{P}_{2}$ liberation, respectively. Scale bars, $20 \mu \mathrm{m}$.

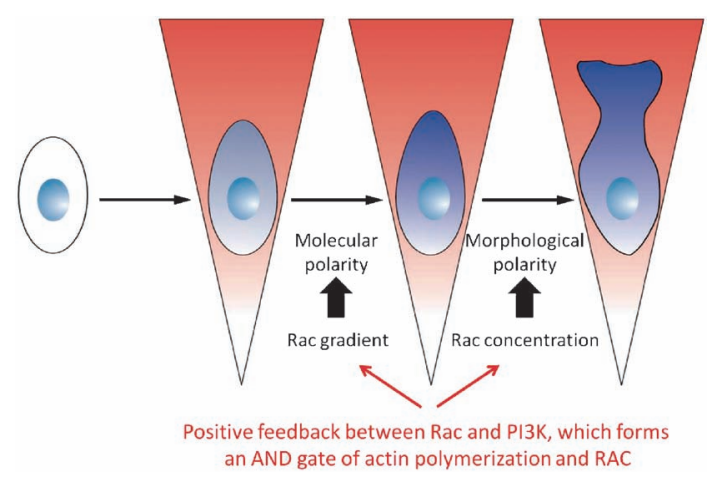

Fig. 5. Molecular Mechanism of Chemotaxis

Using CRISP molecular probes combined with a microfluidics device, we have shown that Rac activity gradient determines molecular polarity inside unpolarized cells, while active Rac concentration regulates ensuing morphological polarity.

ケミカルバイオロジー, 分子生物学, 細胞生物学, バイオエンジニアリング，光学など）の知識を総動 員して達成された新規かつ独創的な摂動ツールであ り，上記の複雑なシグナル様式の精査に非常に有用 となることが期待される．また細胞走化性に関する 一連の研究により, われわれは細胞走化性を引き起 こすために必要な最小限のシグナル様式を理解する ことができた。それは Racによるアクチン重合の 勾配活性である。この知見に基づき，現在 in vitro で細胞走化性を再構築することを目指している，細
胞遊走の再構築に関する知見はわれわれの知る限り では非常に少なく，2000，2009 年にZheng と上口 らが，細胞内の $\mathrm{IP}_{3}$ 及びカルシウム濃度を光で制御 し，神経成長円錐の動きを自在に操つた報告, ${ }^{16,17)}$ 2008 年に筆者らによる CRISP により細胞膜受容体 刺激なしに好中球を遊走させた報告, ${ }^{14)}$ 2009-2010 年にHahn らのプローブを用いた報告4,18,19) があ る.これらはいずれも生きた細胞内の分子活性を光 やラパローグで直接制御することで細胞遊走を引き 起こしている，われわれは，細胞ではなくもっと人 工的な系での再構築を目指し, 膜工学で多用されて いる人工巨大小胞膜（GUV とも呼ばれる）を用い ている. 人工巨大小胞膜は，人工的に作製された脂 質二重膜で, タンパク質や脂質が膜構造に与える影 響を精査する上で非常に有用なモデルシステムであ る. ${ }^{20)}$ 特に膜の構造変化に関する研究で多用されて (る. ${ }^{21)}$ 人工膜の脂質組成は自在に変えることがで き，またタンパク質の導入方法も膜タンパク質を含 めて技術的に確立されている。 まず第一段階として，

FRB を人工膜へ局在させるために必要な脂質修飾 の最適化を行い, 人工膜上で CRISP プローブが適 切に機能するか確認する。次に必要な最小限の分子 群（Rac, WAVE，アクチンとその結合タンパクな ど）を個々に精製し，好中球と同程度の $20 \mu \mathrm{m}$ 前 後の大きさの人工膜内に導入する. 最終的にはラパ ローグへの走化性を達成するため，人工巨大小胞膜 をマイクロ流路系に導入し，ラパローグを勾配状に 加え，人工膜の運動を経時的に蛍光観察する．こう した構成的理解に務める研究は米国ではまだ認知が 乏しく, 研究費の取得が極めて難しい。 われわれの 場合は非常に幸運なことに，日本科学技術機構の支 援を頂くことできた.

\section{結論}

近年の確立されたジェネティクス，発展した生化 学的手法, そして蛍光イメージングの普及に伴い, ある特定の数少ない情報伝達分子が, 多様な細胞機 能を担うことが明らかになってきた，Ras，細胞内 カルシウム, p53, PI $(4,5) \mathrm{P}_{2}, \mathrm{PIP}_{3}$ などはその一例 である。細胞は時々刻々と変化する環境に応じて, 最も適切な機能を選択し生き延びていく。これらの 環境要因には栄養素, 温度, $\mathrm{pH}$, 光, 数百種類の 化学物質などがあり，それらすべての組み合わせは 膨大な数となる。すなわち細胞とは，非常に小さな 
空間で，膨大なインプットに対応し，限られた数の 素子を用いて，適切なアウトプットを生み出す精巧 なデバイスと考えられる。しかしなが，上記の情 報伝達分子は，一般的に活性型と不活性型の 2 つの 状態しかとらない。このように単純なバイナリース イッチの集合がいかにして複雑な情報処理を行って いるのかは生物の根源的な問題である。これをわれ われはシグナリングパラドクスと呼んでいる．細胞 遊走も，限られた分子で非常に複雑な情報処理を行 うことが知られている，そこで CRISP のように生 きた細胞内でシグナル様式を自在に操る技術は， シ グナリングパラドクスを解く鍵として細胞生物学へ の多大な寄与が予測される。 さらに CRISP は細胞 がごのようにして非線形フィードバックシグナルを 作り上げているのか？ また様々な環境下でどのよ うにしてそれを使い分けているのか？ 細胞遊走以 外の細胞機能においても同様のシグナル様式が利用 されているのか？ などの新たな疑問を検証するプ ラットフォームを提供する。 もちろん細胞走化性だ けでなく, 秒から分のオーダーで起こる速い細胞機 能（細胞分裂，細胞融合，細胞輸送など）の研究に も有用であると考えている. 今後の研究も含めて, われわれは細胞遊走をモデル系として，構成生物学 の概念を基にシグナリングパラドクスの解を探索し ていく。こうした研究により得られた知見と開発さ れた技術は，細胞遊走に関連した病態である免疫疾 患やがんの治療戦略にも大いに役立つことを期待す る.

謝辞 ここで紹介した研究成果は，独創的なア イディアと活力に溢れた井上研究室の研究員達のお かげである．特に，CRISP の開発にはポスドクの 小松徹氏，Yu-Chun Lin 氏，宮本崇史氏，大学院 生の梅田暢大氏らが大きな寄与をしてくれた。また ポスドクの上野匡氏は細胞骨格と膜脂質，大学院生 のBen Lin 氏はマイクロ流路系を用いた細胞走化 性の研究を担当し多大な成果を挙げた。 また上野氏 と宮本氏には本原稿に対する建設的な意見だけでな く，校正もして頂き大変感謝している，最後に日本 薬学会には若手奨励賞という過分な評価を頂き，身 に余る思いである.

\section{REFERENCES}

1) Ridley A. J., Schwartz M. A., Burridge K., Firtel R. A., Ginsberg M. H., Borisy G., Parsons J. T., Horwitz A. R., Science, 302, 17041709 (2003).

2) Zigmond S. H., J. Cell. Biol., 75, 606-616 (1977) .

3) Levskaya A., Weiner O. D., Lim W. A., Voigt C. A., Nature, 461, 997-1001 (2009).

4) Wu Y. I., Frey D., Lungu O. I., Jaehrig A., Schlichting I., Kuhlman B., Hahn K. M., Nature, 461, 104-108 (2009).

5) Spencer D. M., Wandless T. J., Schreiber S. L., Crabtree G. R., Science, 262, 1019-1024 (1993).

6) Inoue T., Heo W. D., Grimley J. S., Wandless T. J., Meyer T., Nat. Methods, 2, 415-418 (2005).

7) Komatsu T., Kukelyansky I., McCaffery J. M., Ueno T., Varela L. C., Inoue T., Nat. Methods, 7, 206-208 (2010).

8) Suh B. C., Inoue T., Meyer T., Hille B., Science, 314, 1454-1457 (2006).

9) Heo W. D., Inoue T., Park W. S., Kim M. L., Park B. O., Wandless T. J., Meyer T., Science, 314, 1458-1461 (2006).

10) Umeda N., Ueno T., Pohlmeyer C., Nagano T., Inoue T., J. Am. Chem. Soc., 133, 12-14 (2011).

11) Miyamoto T., DeRose R., Suarez A., Ueno T., Chen M., Sun T.-P., Wolfgang M. J., Mukherjee C., Meyers D., Inoue T., Nat. Chem. Biol., 8, 465-470 (2012).

12) Lin Y. C., Nihongaki Y., Liu T. Y., Razavi S., Sato M., Inoue T., Angew. Chem. Int. Ed., 52, 6450-6454 (2013).

13) Ueno T., Falkenburger B. H., Pohlmeyer C., Inoue T., Sci. Signal., 4, ra87 (2011).

14) Inoue T., Meyer T., PLoS ONE, 3, e3068 (2008) .

15) Lin B., Holmes W. R., Wang C. J., Ueno T., Harwell A., Edelstein-Keshet L., Inoue T., Levchenko A., Proc. Natl. Acad. Sci. USA, 109, E3668-E3677 (2012).

16) Akiyama H., Matsu-ura T., Mikoshiba K., Kamiguchi H., Sci. Signal., 2, ra34 (2009).

17) Zheng J. Q., Nature, 403, 89-93 (2000). 
18) Wang X., He L., Wu Y. I., Hahn K. M., Montell D. J., Nat. Cell Biol., 12, 591-597 (2010).

19) Yoo S. K., Deng Q., Cavnar P. J., Wu Y. I., Hahn K. M., Huttenlocher A., Dev. Cell, 18, 226-236 (2010).
20) Menger F. M., Keiper J. S., Curr. Opin. Chem. Biol., 2, 726-732 (1998).

21) Baumgart T., Capraro B. R., Zhu C., Das S. L., Annu. Rev. Phys. Chem., 62, 483-506 (2011). 